\title{
Varying mesoscale structures influence larval fish distribution in the northern Gulf of Mexico
}

\author{
David Lindo-Atichati ${ }^{1,2,3, *}$, Francis Bringas ${ }^{1,2}$, Gustavo Goni ${ }^{2}$, \\ Barbara Muhling ${ }^{1,4}$, Frank E. Muller-Karger ${ }^{5}$, Sennai Habtes ${ }^{5}$ \\ ${ }^{1}$ University of Miami, Cooperative Institute for Marine and Atmospheric Studies, Miami, Florida 33149, USA \\ ${ }^{2}$ Atlantic Oceanographic and Meteorological Laboratory and ${ }^{4}$ Southeast Fisheries Science Center, \\ National Oceanic and Atmospheric Administration, Miami, Florida 33149, USA \\ ${ }^{3}$ Universidad de Las Palmas de Gran Canaria, Facultad de Ciencias del Mar, Las Palmas de Gran Canaria 35017, Spain \\ ${ }^{5}$ Department of Marine Science, University of South Florida, St. Petersburg, Florida 33701, USA
}

\begin{abstract}
The variability of mesoscale circulation structures in the Gulf of Mexico (GOM) was examined using satellite altimeter data collected between 1992 and 2008, and linkages between ocean circulation and the spatial distribution of larval fish were assessed. The abundance and distribution of the larvae of 5 pelagic fish taxa (Auxis spp., Euthynnus alleteratus, Thunnus thynnus, other Thunnus spp., and Coryphaena spp.) were estimated from surveys conducted by the National Oceanic and Atmospheric Administration National Marine Fisheries Service each spring between 1993 and 2007. We observed a tendency for higher northward extension of the Loop Current (LC) during spring each year, with maximum northern penetration in summer, although the exact location of the LC varied from year to year. Generally, higher total larval abundances occurred during years of high northward penetration in a region that was crossed by the LC during its excursions. However, the interannual variability of the LC was not mirrored in a general increase or decrease of larval fish densities in the water masses out of the LC front. Further, the results show that larvae of $T$. thynnus and Auxis spp. were more abundant within the boundaries of anticyclonic features (usually between 148 to $158 \mathrm{~cm}$ of sea surface height) and within GOM common waters, defined as the background waters in between the boundaries of mesoscale features. Our findings suggest that the position and strength of anticyclone mesoscale features in the GOM define a favorable spawning habitat for the species examined.
\end{abstract}

KEY WORDS: Fisheries oceanography · Mesoscale variability · Fronts and eddies · Loop Current · Ichthyoplankton distribution · Thunnus thynnus

Resale or republication not permitted without written consent of the publisher

\section{INTRODUCTION}

The Gulf of Mexico (GOM) is a favorable spawning habitat for several commercially important pelagic and benthic fish species (Rabalais et al. 1999, Shipp 1999). This basin is also characterized by a complex and highly variable system of currents and eddies, which affects the physical environment where fish spawn (Teo \& Block 2010). The mesoscale circulation in the GOM is dominated by the Loop Current (LC) and rings shed by this major current (Fig. 1). The LC flows into the GOM through the Yucatan Channel as the Yucatan Current, with some secondary flow reversals observed along the margins of the Yucatan Peninsula and along Cuba. Southward flow is also observed deep within the Yucatan Channel, at depths exceeding 600 to $800 \mathrm{~m}$ below the northward flow of the Yucatan Current (Candela et al. 2002, 


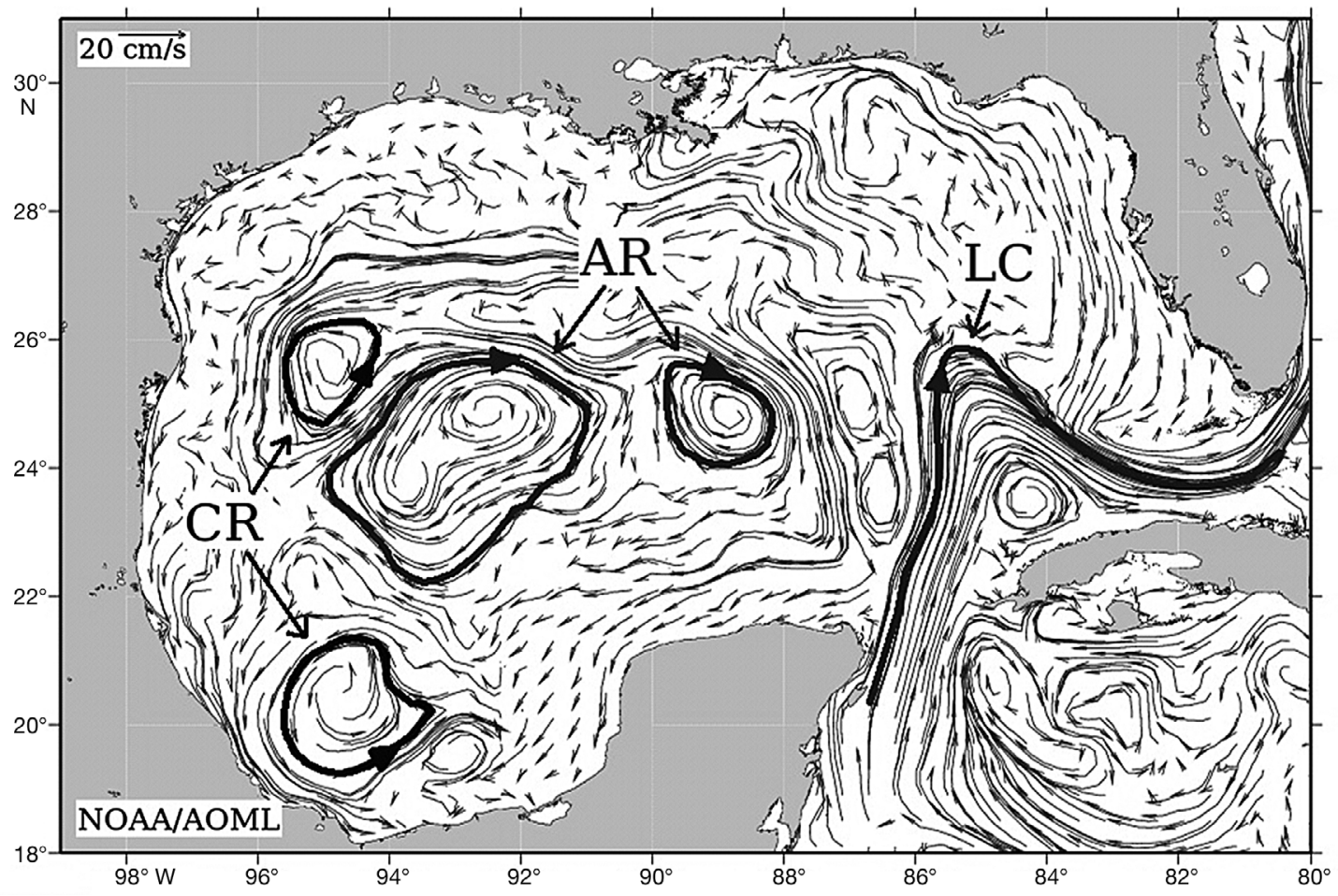

Fig. 1. General circulation in the Gulf of Mexico on 22 October 2010. Thin arrows represent geostrophic currents derived by combining satellite altimeter observations and numerical model results. Thick arrows contour anticyclonic Loop Current (LC) and rings $(\mathrm{AR})$ and cyclonic rings $(\mathrm{CR})$

2003). Upon entering the GOM, the flow of water has an intense anticyclonic flow, known as the Loop Current. This current can extend as far north as $29.1^{\circ} \mathrm{N}$, within close proximity to the Mississippi River delta or the Florida Panhandle coast (Molinari \& Mayer 1982). Although the LC intrusion into the northern GOM is often observed in spring, it may occur during any time of the year. The cycle of extension and contraction of the Loop Current varies from 6 to 17 mo (Molinari 1980), with an average period of 10 to 11 mo (Maul \& Vukovich 1993). The LC returns to its southern location, where water from the Yucatan Current flows more directly toward the Straits of Florida, after the northern extension of the LC is pinched off. This process forms large anticyclonic rings which then propagate westward at speeds of 2 to $5 \mathrm{~km} \mathrm{~d}^{-1}$, with a lifetime of days to $\sim 1 \mathrm{yr}$ (Elliott 1982, Forristall et al. 1992, Shay et al. 1998). These anticyclonic rings have radii of $\sim 150 \mathrm{~km}$ and swirl speeds of 1.8 to $2 \mathrm{~m} \mathrm{~s}^{-1}$ and can reach $\sim 800 \mathrm{~m}$ depth (Oey et al. 2005). The average time between consecutive ring sheddings is $9.5 \mathrm{mo}$, with a range of 3 to 21 mo (Sturges \& Leben 2000, Zavala-Hidalgo et al. 2006). The annual fluctuations in LC flow have been attributed to wind forcing (Sturges \& Evans 1983) and to variations in the inflow of water from the
Caribbean (Lee et al. 1995, Oey et al. 2003, AlveraAzcárate et al. 2009).

Knowledge of the temporal and spatial variability of mesoscale structures in the GOM is fundamental for understanding the distribution of larvae of pelagic fish, their spawning habitat, and food availability for larvae (Ortner et al. 1978, 1984, Davis \& Wiebe 1985, Richards et al. 1993, Medina et al. 2002, Royer et al. 2004, Wilson et al. 2005, Bakun 2006). Both anticyclonic and cyclonic eddies have been shown to positively affect the abundance and distribution of plankton and fish larvae in other regions of the ocean (Nakata et al. 2000, Okazaki et al. 2002).

Physical and biological conditions in the GOM exhibit high spatial and temporal variability (MullerKarger et al. 1991). The National Marine Fisheries Service (NMFS) Southeast Area Monitoring and Assessment Program (SEAMAP) surveys conducted in spring 1987 showed higher displacement volumes of plankton and higher densities of fish larvae, including Carangidae, Myctophidae, Thunnus thynnus, and other Scombridae in LC frontal areas (Richards et al. 1989, 1993). Recent studies showed that adult $T$. thynnus and Istiophorus platypterus appear to target specific habitats or oceanographic features to spawn (Muhling et al. 2010, Richardson et al. 2009). 
The objective of the present study is to assess the influence of mesoscale ocean features on the distribution of larvae of Thunnus thynnus, Euthynnus alleteratus, Thunnus spp., Auxis spp., and Coryphaena spp. offshore in the northern GOM in spring months from 1993 to 2007 . An improved understanding of larval distribution in different water masses, characterized by circulation and sea surface height (SSH), will provide a benchmark for future coupled biophysical studies and habitat models in the region.

\section{MATERIALS AND METHODS}

\section{Satellite data}

Boundaries of mesoscale features in the GOM have frequently been defined using sea surface temperature (SST) and ocean color observations from satellites and a more limited number of hydrographic observations (e.g. Breaker 1981, Maul et al. 1984, Richards et al. 1989, Muller-Karger et al. 1991, Bigelow et al. 1999, Royer et al. 2004). Satellitederived observations of SSH and sea height anomaly (SHA), SST, and ocean color offer sufficient temporal and spatial resolution to study the evolution of the main surface mesoscale features in the region. Altimetry measurements have shown great utility in biophysical studies (e.g. Polovina et al. 1999, Chiswell et al. 2003, Rudorff et al. 2009) and can be used to monitor surface ocean features year-round. For example, SST, SHA, SSH, and the gradient of $\mathrm{SSH}$ fields clearly show the structure of the LC and an anticyclonic ring in May 1998 (Fig. 2a-d). Conversely, during the month of June 1998, the LC and the ring cannot be easily detected from SST observations (Fig. 2e) due to the lack of marked gradients as the surface of the GOM warmed up. However, these features are clearly distinguishable using altimetry observations (Fig. 2f, $g, h$ ).

SST fields were obtained from a number of satellite sources. Optimally interpolated SST fields were obtained from microwave observations retrieved by the TRMM Microwave Imager (TMI) and Advanced Microwave Scanning (AMSR-E) radiometers onboard the Tropical Rainfall Measuring Mission (TRMM) and Aqua satellites, respectively (http:// trmm.gsfc.nasa.gov/, http://nsidc.org/data/amsre/). These daily fields have a spatial resolution of $0.25^{\circ}$. SST observations from the Advanced Very High Resolution Radiometer (AVHRR) were available with a resolution of $2 \mathrm{~d}$ and $18 \mathrm{~km}$ equal-area grid (Ryan et al. 1996).
The altimetric observations used in the present study were obtained from between 2 and 4 satellites operating during the period covered by our study. Altimetry data were then optimally interpolated according to an improved objective analysis (Le Traon et al. 1998) with a resolution of $0.25^{\circ}$ and $1 \mathrm{wk}$.

Because of uncertainties in the geoid, altimeter data are generally estimated as variations around mean sea level. To obtain an estimate of the geostrophic component of the circulation, it is therefore necessary to add a mean dynamic height field to the anomalies. The absolute geostrophic velocities derived from the satellite altimeter measuring $\mathrm{SSH}$ were obtained from the French Archiving, Validation and Interpretation of Satellite Oceanographic data (AVISO) system using the mean dynamic topography (MDT) of the ocean (Rio \& Hernandez 2004) as follows:

$$
\mathrm{SSH}(\mathrm{cm})=\mathrm{SHA}(\mathrm{cm})+\mathrm{MDT}(\mathrm{cm})
$$

The reliability of geostrophic currents derived from altimetry have been validated in the region (Blaha et al. 2000, Powell et al. 2006), for example, by comparing them to drifter trajectories during the Deep Water Horizon oil spill, when a number of drifters were deployed in the region (Liu et al. 2011).

\section{Spatial variability of LC front and local oceanographic feature identification}

The LC is characterized by an SSH greater than the surrounding waters, and its position can be determined from the horizontal gradient of SSH. Specifically, the northernmost, westernmost, and easternmost locations of the LC were measured by obtaining the maximum latitude, maximum longitude, and minimum longitude of the SSH contours corresponding to the location of the maximum gradient of $\mathrm{SSH}$ (e.g., red regions in Fig. 2d,h). The spatial variability of the LC was studied in terms of northward penetration of the front using the 768 weekly fields of SSH gradient in the GOM. One-way ANOVA was employed to test the seasonal variability of the northern intrusion of the LC.

Our approach to studying the distribution of larval fish in the LC included defining a region of influence (ROI) of the LC. The ROI was the area limited by the northernmost latitude, westernmost longitude, and easternmost longitudes of the LC front and was estimated weekly. These locations were compared with the weekly collections of the in situ fish larvae surveys from 26 April 1993 to 29 May 2007. 

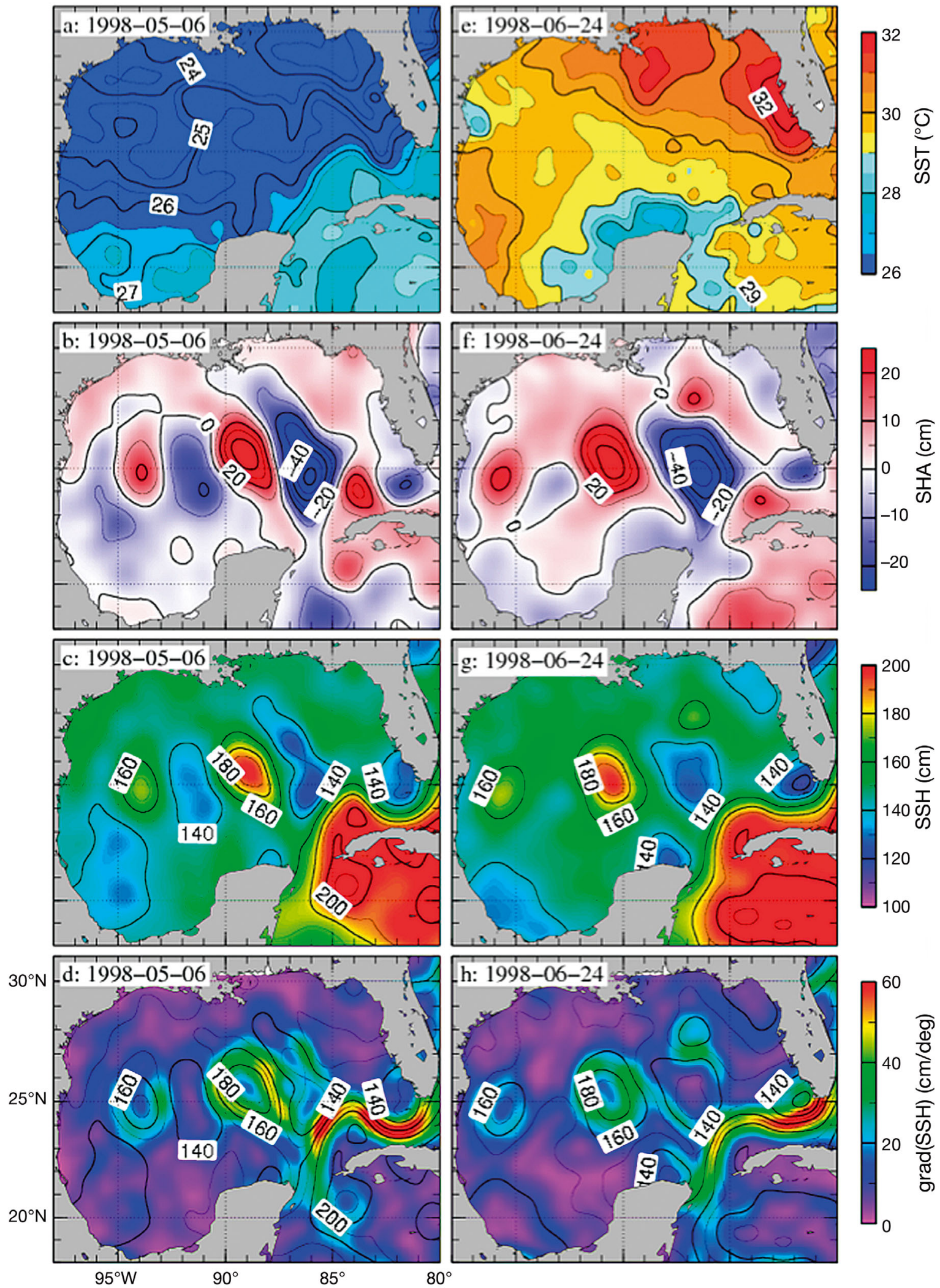

Fig. 2. SST and SSH satellite-derived fields. (a-d) Ring separation event in terms of (a) SST, (b) SHA, (c) SSH, and (d) gradient of SSH on 6 May 1998. (e-h): Ring already shed by the Loop Current in terms of (e) SST, (f) SHA, (g) SSH, and (h) gradient of SSH on 24 June 1998. SST: sea surface temperature, SSH: sea surface height, SHA: sea surface height anomaly 
To identify the main mesoscale features in the GOM outside the LC ROI and relate them to larval fish densities outside the LC ROI waters, we classified every grid point in the altimeter fields to have 1 of the following 5 characteristics:

a) An anticyclonic region (AR):

$$
\mathrm{SSH} \geq \mathrm{SSH}_{\max }-n \cdot \mathrm{SD}(\mathrm{SSH})
$$

b) A cyclonic region (CR):

$$
\mathrm{SSH} \leq \mathrm{SSH}_{\min }+p \cdot \mathrm{SD}(\mathrm{SSH})
$$

c) An anticyclonic region boundary $(\mathrm{AB})$ :

$$
\begin{gathered}
\mathrm{SSH} \geq m \cdot \mathrm{SSH}_{\max } \\
\text { and } \operatorname{grad}(\mathrm{SSH}) \geq r \cdot \mathrm{SD}(|\operatorname{grad}(\mathrm{SSH})|)
\end{gathered}
$$

d) A cyclonic region boundary $(\mathrm{CB})$ :

$$
\begin{gathered}
\mathrm{SSH} \leq q \cdot \mathrm{SSH}_{\min } \\
\text { and } \operatorname{grad}(\mathrm{SSH}) \geq r \cdot \mathrm{SD}(|\operatorname{grad}(\mathrm{SSH})|)
\end{gathered}
$$

tions of Coryphaena spp., Thunnus spp., Auxis spp. T. thynnus, or Euthynnus alleteratus. Negative stations are those with no captures of any of the previous taxa. The total number of sampled stations was considered in the present study, incorporating into the dataset the number of negative stations. Cruises were divided into 2 legs and were conducted throughout the United States Exclusive Economic Zone in the northern GOM only. Most of the sampling effort was focused on a $1^{\circ}$ grid of stations, and this grid was usually completed twice each spring, with the exception of 2003 and 2004, when the grid was sampled only once. Additional stations were sampled in 1994, 1995, and 2007. Between 42 and 217 hydrographic-plankton stations were carried out each year, with an average of 93 positive stations and 15 negative stations per survey in the $15 \mathrm{yr}$ covered by the present study. At each station, plankton

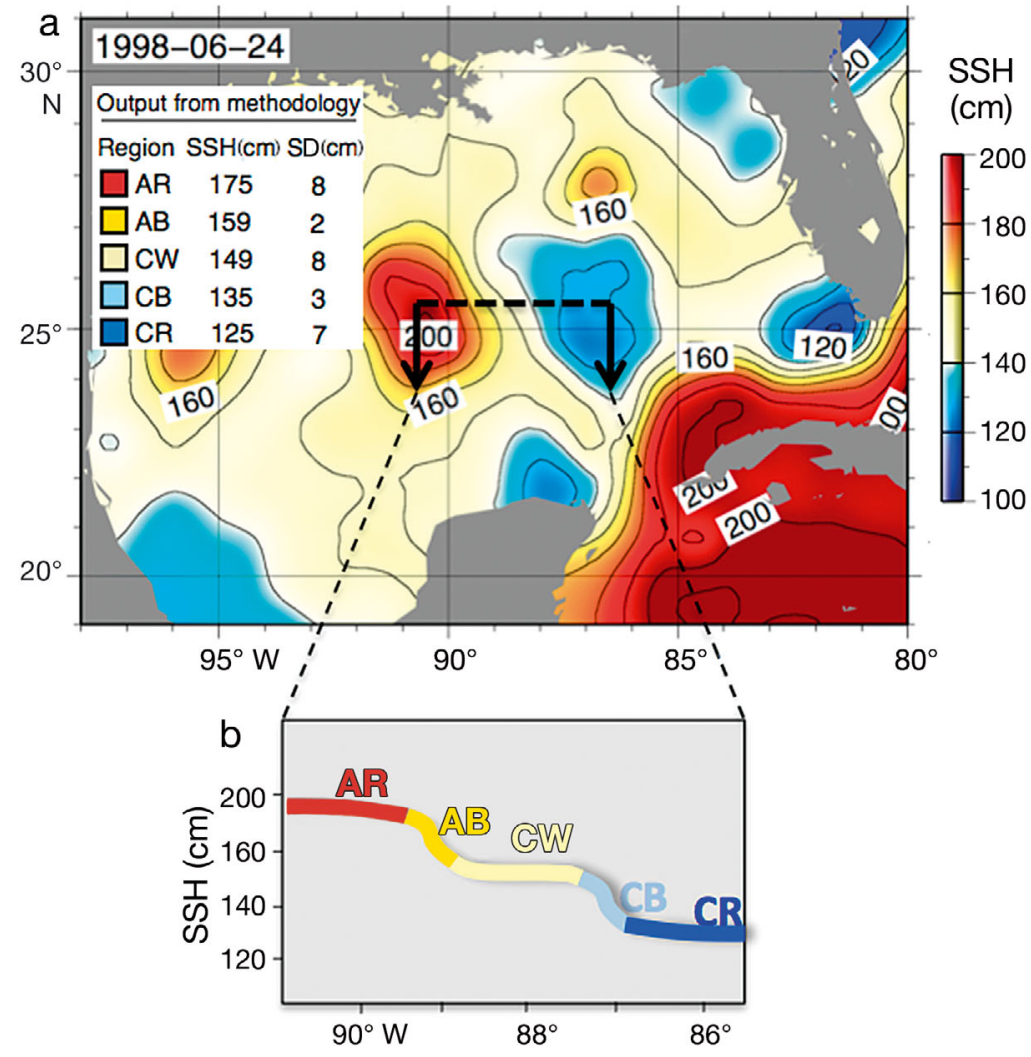

Fig. 3. (a) Example of the 5 regions of circulation and boundaries defined using the mesoscale classification algorithm for 24 June 1998. The regions and boundaries are categorized as anticyclonic regions $(\mathrm{AR})$, anticyclonic boundaries $(\mathrm{AB})$, common waters $(\mathrm{CW})$, cyclonic boundaries (CB), and cyclonic regions (CR). The background field is the satellite-derived SSH. The key in (a) illustrates the SSH (mean \pm $\mathrm{SD})$ for each region of circulation. The colorscale corresponds to the colors of the satellite-derived SSH field. (b) shows how the algorithm classifies water masses in a section between 2 mesoscale ocean features. $\mathrm{SSH}=$ sea surface height base. Positive stations are those with collec- 
Table 1. SEAMAP stations sampled with a bongo net between 1993 and 2007 across the northern GOM. For each period and region, the total number of sampled stations is shown. Parentheses: no. of stations containing Coryphaena spp., Thunnus spp., Auxis spp., T. thynnus, Euthynnus alleteratus, or negative stations (no captures of the previous taxa), respectively

\begin{tabular}{|llll|}
\hline Year & Sampling date & Region sampled & No. of sampled stations \\
\hline 1993 & 26 April - 15 June & $24-30^{\circ} \mathrm{N} / 84-96^{\circ} \mathrm{W}$ & $105(9,33,21,8,11,23)$ \\
1994 & 28 April - 9 June & $24-29^{\circ} \mathrm{N} / 84-96^{\circ} \mathrm{W}$ & $185(23,70,40,20,10,22)$ \\
1995 & 19 April - 7 June & $24-30^{\circ} \mathrm{N} / 84-96^{\circ} \mathrm{W}$ & $157(6,55,38,18,16,24)$ \\
1996 & 17 April - 25 May & $24-29^{\circ} \mathrm{N} / 83.5-96^{\circ} \mathrm{W}$ & $82(4,12,24,12,10,20)$ \\
1997 & 17 April - 9 June & $24-30^{\circ} \mathrm{N} / 84-96^{\circ} \mathrm{W}$ & $98(13,2,35,9,7,32)$ \\
1998 & 26 April - 23 June & $24-29^{\circ} \mathrm{N} / 84-96^{\circ} \mathrm{W}$ & $117(9,39,22,10,11,26)$ \\
1999 & 24 April - 31 May & $24-29^{\circ} \mathrm{N} / 83.5-96^{\circ} \mathrm{W}$ & $87(8,34,16,10,3,16)$ \\
2000 & 20 April - 26 May & $24-30^{\circ} \mathrm{N} / 83.5-95^{\circ} \mathrm{W}$ & $110(17,50,21,11,6,5)$ \\
2001 & 18 April - 29 May & $24-29^{\circ} \mathrm{N} / 83.5-96^{\circ} \mathrm{W}$ & $110(18,40,16,18,4,15)$ \\
2002 & 19 April - 28 May & $24-29^{\circ} \mathrm{N} / 83.5-96^{\circ} \mathrm{W}$ & $75(1,22,18,9,7,18)$ \\
2003 & 13 May - 30 May & $24-29^{\circ} \mathrm{N} / 83.5-96^{\circ} \mathrm{W}$ & $95(6,53,17,14,1,4)$ \\
2004 & 13 May - 30 May & $25-29^{\circ} \mathrm{N} / 84-96^{\circ} \mathrm{W}$ & $44(2,16,14,6,4,2)$ \\
2005 & 23 April - 17 July & $24-30^{\circ} \mathrm{N} / 83.5-96^{\circ} \mathrm{W}$ & $108(4,36,26,18,8,16)$ \\
2006 & 23 April - 16 July & $24-30^{\circ} \mathrm{N} / 84-97^{\circ} \mathrm{W}$ & $42(2,22,9,6,3,0)$ \\
2007 & 17 April - 29 May & $24-30^{\circ} \mathrm{N} / 84-96^{\circ} \mathrm{W}$ & $217(12,86,57,24,26,12)$ \\
\hline
\end{tabular}

was collected with bongo nets, and CTD casts were completed.

Bongo net tows were generally completed across the grid of stations in the GOM in late April and May, with sampling continuing into late June in some years. Sampling extended to July in 2005 and 2006 (Table 1). Bongo nets were fitted with $333 \mu \mathrm{m}$ mesh, on two $61 \mathrm{~cm}$ diameter round frames, and were towed obliquely to $200 \mathrm{~m}$ depth or to just above the bottom at shallower stations (Richards et al. 1993). Nets were towed at 2 to 3 knots, and sampling took place during both day and night. Samples from bongo nets were sorted, and larvae were identified to the lowest possible taxa at the Sea Fisheries Institute, Plankton Sorting and Identification Center, Gdynia and Szczecin, Poland.

The abundance of larvae captured was standardized to larval densities (number of larvae per $\mathrm{m}^{2}$ ) by estimating the volume filtered using a flow-meter fitted to the bongo net and integrating to the towing depth at each station.

\section{Larval fish identification and taxonomy}

The spring plankton surveys were originally designed to target Thunnus thynnus larvae. However, larvae of $>500$ taxa were recorded over the duration of the surveys. In the present study, larvae of 5 taxa from 3 commercially important families were analyzed. In many cases, larvae from closely related species were not distinguishable visually, so larval groups were merged at the genus level. Larvae of Coryphaenidae (Coryphaena spp. hereafter, likely incorporating $C$. hippurus and $C$. equiselis) were analyzed at genus level. Within the family Scombridae (tunas), Auxis larvae (Auxis spp. hereafter, likely incorporating larvae of $A$. rochei rochei and $A$. thazard thazard) were analyzed at genus level, as were Thunnus larvae (Thunnus spp. hereafter, likely a mix of T. albacares and T. atlanticus and not including $T$. thynnus). Larvae of both T. thynnus and Euthynnus alleteratus were visually distinguishable from other tuna species and were therefore analyzed at the species level.

\section{Data analysis}

Associations between larval catches of Thunnus thynnus, Euthynnus alleteratus, Thunnus spp., Auxis spp., and Coryphaena spp. and the interannual variability of the LC were determined using a time series of the mean larval density of all taxa (larvae $\mathrm{m}^{-2}$ ) on a square bin of $2^{\circ}$ centered at the mean northernmost latitude and westernmost longitude of the LC during spring months. Outside the LC ROI, associations between larval catches and the inner and outer regions of the mesoscale features were determined by the proportion of positive stations (\%) and mean larval densities (larvae $\mathrm{m}^{-2}$ ) within mesoscale ocean features. The capture locations of each taxon - outside the LC ROI - were classified as 1 of 5 different categories $(\mathrm{AR}, \mathrm{AB}, \mathrm{CR}, \mathrm{CB}$, or $\mathrm{CW})$. Once the sampled station was classified to be in 1 of the 5 ocean mesoscale features, the proportion of positive stations of a taxon within that feature was calculated as the number of positive stations of the taxon in the ocean feature divided by the total number of stations (including positive and negative stations). The mean larval density for each taxa and mean larval density of all 5 taxa together (total) in each mesoscale feature were also calculated and analyzed.

Permutational multivariate analysis of variance (PERMANOVA; Anderson 2001) was used to test the null hypothesis of no difference among the 5 regions of circulation in (1) total abundances of the 5 taxa, (2) the species assemblages of the 5 taxa, (3) 


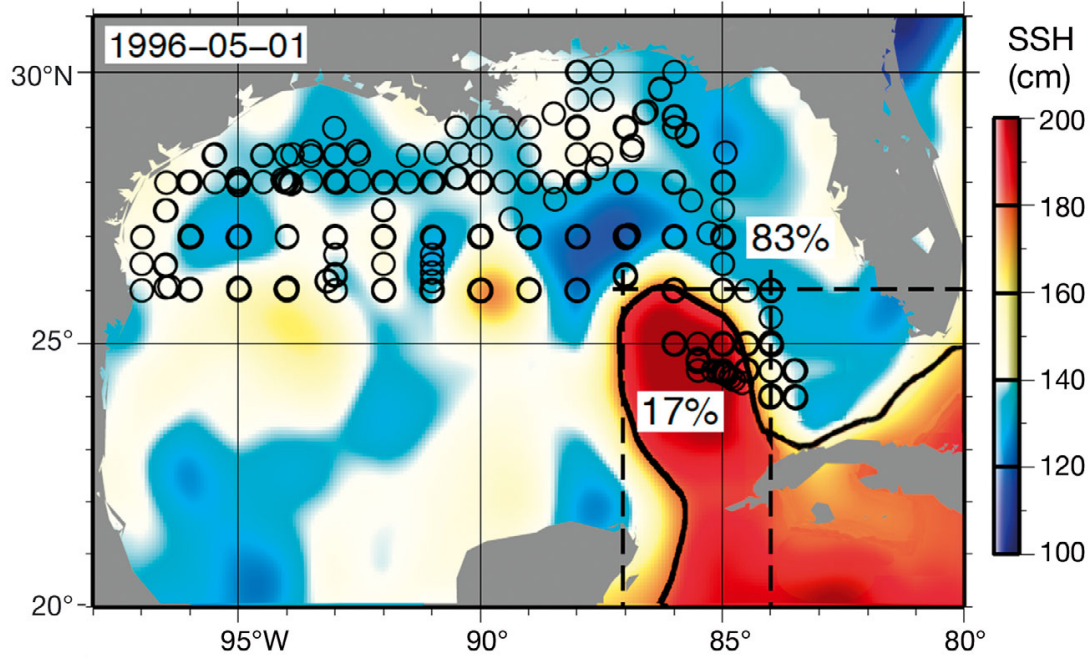

Fig. 4. Station locations (O) of the NOAA/SEFSC SEAMAP annual larvae survey and percentage of larval fish captured in $(17 \%)$ and out $(83 \%)$ of the LC ROI from 1993 to 2007. The background color is the satellite derived sea surface height (SSH) for 1 May 1996. The dashed lines illustrate the northernmost latitude, westernmost longitude and easternmost longitude of the LC front in the GOM north of $23^{\circ} \mathrm{N}$, which were $26^{\circ} \mathrm{N}, 87^{\circ} \mathrm{W}$, and $84^{\circ} \mathrm{W}$. LC: Loop Current; ROI: region of influence

individual abundances of each taxon that differed, and (4) the presence/absence (occurrence) of each taxon. Primer 6 software was used to run 999 unique permutations for each of the previous null hypotheses (Clarke \& Gorley 2006). In the present manuscript, we followed the definition of Clarke \& Warwick (2001) and used 'assemblage' to refer to 5 specific taxonomic groups (see also Anderson et al. 2004, Clarke et al. 2006).

\section{RESULTS}

\section{The LC and larval fish distribution}

Between 1993 and 2007, 1632 stations with paired satellite and larval density data were available for analysis (Table 1). A total of 1398 of these stations were positive for at least 1 of the 5 taxa, and 234 were negative, representing $85 \%$ and $15 \%$ of the stations, respectively. Of the 1632 stations sampled across the northern GOM, $9 \%$ contained Coryphaena spp., $35 \%$ Thunnus spp., $23 \%$ Auxis spp., $12 \%$ T. thynnus, and $8 \%$ Euthynnus alleteratus.

Weekly values of northernmost latitude, westernmost longitude, and easternmost longitude of the LC were used to delimit the LC ROI. The ROI fluctuated between $25^{\circ} \mathrm{N}$ and $28^{\circ} \mathrm{N}$ on its northern boundary, from $86^{\circ} \mathrm{W}$ to $89^{\circ} \mathrm{W}$ on its western boundary, and from $83^{\circ} \mathrm{W}$ to $85^{\circ} \mathrm{W}$ on its eastern boundary. From 1993 to 2007, the mean northernmost, westernmost, and easternmost locations of the ROI of the LC were $26^{\circ} \mathrm{N}, 87^{\circ} \mathrm{W}$, and $84^{\circ} \mathrm{W}$, respectively, and the percentage of captures (mean $\pm \mathrm{SD}$ ) in the weekly ROI of the LC was $17 \pm$ $10 \%$ (Fig. 4). The larval fish collected in the ROI of the LC for each sampling period ranged from 11 larval fish in 2006 (3\% of the larval fish captured) to 166

Table 2. Details of sampled SEAMAP stations between 1993 and 2007 across the northern GOM. Parentheses: larvae of Coryphaena spp., Thunnus spp., Auxis spp., T. thynnus, and E. alleteratus, respectively, that were collected

\begin{tabular}{|c|c|c|c|c|c|}
\hline Year & Sampling date & No. of larvae collected & $\mathrm{LC}$ ROI $\left({ }^{\circ}\right)$ & $\begin{array}{l}\text { No. of larvae } \\
\text { collected in LC ROI }\end{array}$ & $\begin{array}{c}\text { Larvae in LC } \\
\text { ROI (\%) }\end{array}$ \\
\hline 1993 & 26 April - 15 June & $350(10,111,178,25,26)$ & $28^{\circ} \mathrm{N}, 88^{\circ} \mathrm{W}, 85^{\circ} \mathrm{W}$ & $51(4,17,13,17,0)$ & 15 \\
\hline 1994 & 28 April - 9 June & $499(28,161,232,40,38)$ & $26^{\circ} \mathrm{N}, 88^{\circ} \mathrm{W}, 85^{\circ} \mathrm{W}$ & $30(4,11,14,0,1)$ & 6 \\
\hline 1995 & 19 April - 7 June & $424(8,197,131,53,35)$ & $27^{\circ} \mathrm{N}, 88^{\circ} \mathrm{W}, 84^{\circ} \mathrm{W}$ & $128(5,80,23,4,16)$ & 30 \\
\hline 1996 & 17 April - 25 May & $367(5,72,131,53,35)$ & $26^{\circ} \mathrm{N}, 87^{\circ} \mathrm{W}, 84^{\circ} \mathrm{W}$ & $86(2,22,52,3,7)$ & 23 \\
\hline 1997 & 17 April - 9 June & $191(16,6,101,35,33)$ & $25^{\circ} \mathrm{N}, 86^{\circ} \mathrm{W}, 84^{\circ} \mathrm{W}$ & $32(2,0,22,0,8)$ & 17 \\
\hline 1998 & 26 April - 23 June & $539(9,144,289,16,81)$ & $25^{\circ} \mathrm{N}, 86^{\circ} \mathrm{W}, 83^{\circ} \mathrm{W}$ & $166(6,46,57,0,57)$ & 31 \\
\hline 1999 & 24 April - 31 May & $190(10,94,52,29,5)$ & $27^{\circ} \mathrm{N}, 88^{\circ} \mathrm{W}, 85^{\circ} \mathrm{W}$ & $40(2,28,6,4,0)$ & 21 \\
\hline 2000 & 20 April - 26 May & $397(17,259,77,30,14)$ & $27^{\circ} \mathrm{N}, 88^{\circ} \mathrm{W}, 84^{\circ} \mathrm{W}$ & $155(7,99,40,1,8)$ & 39 \\
\hline 2001 & 18 April - 29 May & $264(27,108,31,60,38)$ & $25^{\circ} \mathrm{N}, 87^{\circ} \mathrm{W}, 85^{\circ} \mathrm{W}$ & $12(0,10,0,0,2)$ & 5 \\
\hline 2002 & 19 April - 28 May & $276(5,114,84,42,31)$ & $25^{\circ} \mathrm{N}, 86^{\circ} \mathrm{W}, 84^{\circ} \mathrm{W}$ & $35(4,23,7,0,1)$ & 13 \\
\hline 2003 & 13 May - 30 May & $145(3,75,25,38,4)$ & $28^{\circ} \mathrm{N}, 89^{\circ} \mathrm{W}, 85^{\circ} \mathrm{W}$ & $27(12,7,2,6,0)$ & 19 \\
\hline 2004 & 13 May - 30 May & $125(4,45,42,30,4)$ & $27^{\circ} \mathrm{N}, 88^{\circ} \mathrm{W}, 85^{\circ} \mathrm{W}$ & $14(0,11,3,0,0)$ & 11 \\
\hline 2005 & 23 April - 17 July & $417(9,130,134,44,100)$ & $28^{\circ} \mathrm{N}, 89^{\circ} \mathrm{W}, 85^{\circ} \mathrm{W}$ & $70(4,39,23,4,0)$ & 17 \\
\hline 2006 & 23 April - 16 July & $398(6,171,117,34,70)$ & $27^{\circ} \mathrm{N}, 88^{\circ} \mathrm{W}, 85^{\circ} \mathrm{W}$ & $11(1,7,2,1,0)$ & 3 \\
\hline 2007 & 17 April - 29 May & $253(10,114,87,34,8)$ & $25^{\circ} \mathrm{N}, 86^{\circ} \mathrm{W}, 84^{\circ} \mathrm{W}$ & $18(2,14,1,1,0)$ & 7 \\
\hline
\end{tabular}




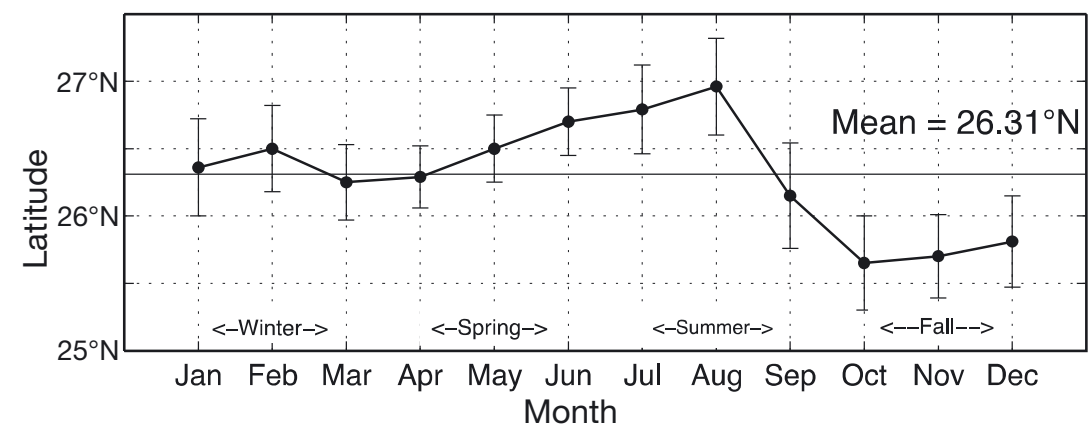
the 16 yr of data (January 1993 to December 2008)
Fig. 5. Monthly location of the LC northward penetration. Means \pm 1 SD over

regression analysis (Fig. 6f) showed that oscillations of the LC about its mean latitude (Fig. 6c) were significantly correlated with larval densities $\left(\mathrm{R}^{2}=0.71, \mathrm{p}<0.001\right)$. Northern or southern excursions of the LC usually led to an increase or decrease in mean larval fish densities in a region that was crossed by the LC during its excursions. For example, in spring 1998, an extreme southern excursion of the LC translated to only 4 larvae collected within this subarea, corresponding to a mean density of 0.25 larvae $\mathrm{m}^{-2}$. However, the interannual variability of the LC was not mirrored in a general increase/decrease of larval-fish densities in the water masses out of the ROI of the LC (Fig. 6e), with no significant correlation found (Fig. 6g).

\section{Effects of other mesoscale structures on larval fish distributions}

$24.25^{\circ} \mathrm{N}$ to $28.50^{\circ} \mathrm{N}$ (Fig. 5). The northernmost location of the LC showed some seasonal variability, with summer (July through August) showing maximum average latitudes and fall and winter (October through December) showing minimum latitudes; however, this was not significant among seasons (1-way ANOVA, F =0.41, p=0.74).

To further analyze the relationship between LC excursions and larval fish distribution, larval fish collections were examined within a square bin of $2^{\circ}$ centered at $26^{\circ} \mathrm{N}$ and $87^{\circ} \mathrm{W}$, which represents the mean northernmost latitude and westernmost longitude of the LC during spring months (Fig. 6a). Spring mean larval density of all taxa was also examined within the area out of the weekly ROI of the LC (Fig. 6b). The time series of deviations from the mean northernmost location of LC in spring, the time series of mean larval concentrations of all taxa in the $2^{\circ}$ box, and the time series of mean larval concentrations of all taxa in water masses out of the weekly ROI of the LC are presented (Fig. 6c,d,e) and analyzed (Fig. 6f,g).

During spring, the LC was usually to the north of its mean location at $26.31^{\circ} \mathrm{N}$ (Fig. 5). However, the LC springtime northward excursions exhibited a yearto-year variability, which ranged from a minimum mean latitude of $24.23^{\circ} \mathrm{N}$ in 2002 to a maximum mean latitude of $27.92^{\circ} \mathrm{N}$ in 2005 (Fig. 6c). Similar year-to-year variability was found in the mean density of captures of fish larvae in the region within $86^{\circ} \mathrm{W}$ to $88^{\circ} \mathrm{W}$ and from $25^{\circ} \mathrm{N}$ to $27^{\circ} \mathrm{N}$ (Fig. 6d). A
The mean percentage of captures (mean \pm SD) outside of the weekly ROI of the LC was $83 \pm 15 \%$. In this region, the proportion of positive stations was higher in $\mathrm{CW}$ and in $\mathrm{AB}$ than in $\mathrm{AR}, \mathrm{CR}$, or $\mathrm{CB}$ for each taxon analyzed here (Table 3 ). Although exploratory, this result gives some insight into how larvae may be distributed within mesoscale ocean features outside the ROI of the LC. Mean larval densities of Thunnus thynnus and Thunnus spp. were higher in the boundaries of anticyclonic features, and larval distributions of Auxis spp. were higher in common waters. Mean larval densities of Euthynnus alleteratus and Coryphaena spp. appear to be similar in $\mathrm{CW}$ and in $\mathrm{AB}$.

Permutational multivariate analysis of variance (PERMANOVA; Anderson 2001) was used to test the significance of previous results and show for which species and regions there was a statistically significant difference. The mean larval densities of all 5 taxa together (total densities) differed significantly among regions $(p=0.001)$, and this was a result of larval densities within $\mathrm{CW}$ being significantly greater than within AR ( $p=0.001), C B(p=$ $0.015)$, and $C R(p=0.009)$. A multivariate analysis among the 5 regions using larval densities of each different taxon indicated that there was a significant difference in the assemblage among regions when all 5 taxa were considered $(p=0.001)$. A pairwise analysis showed that CW was significantly different 


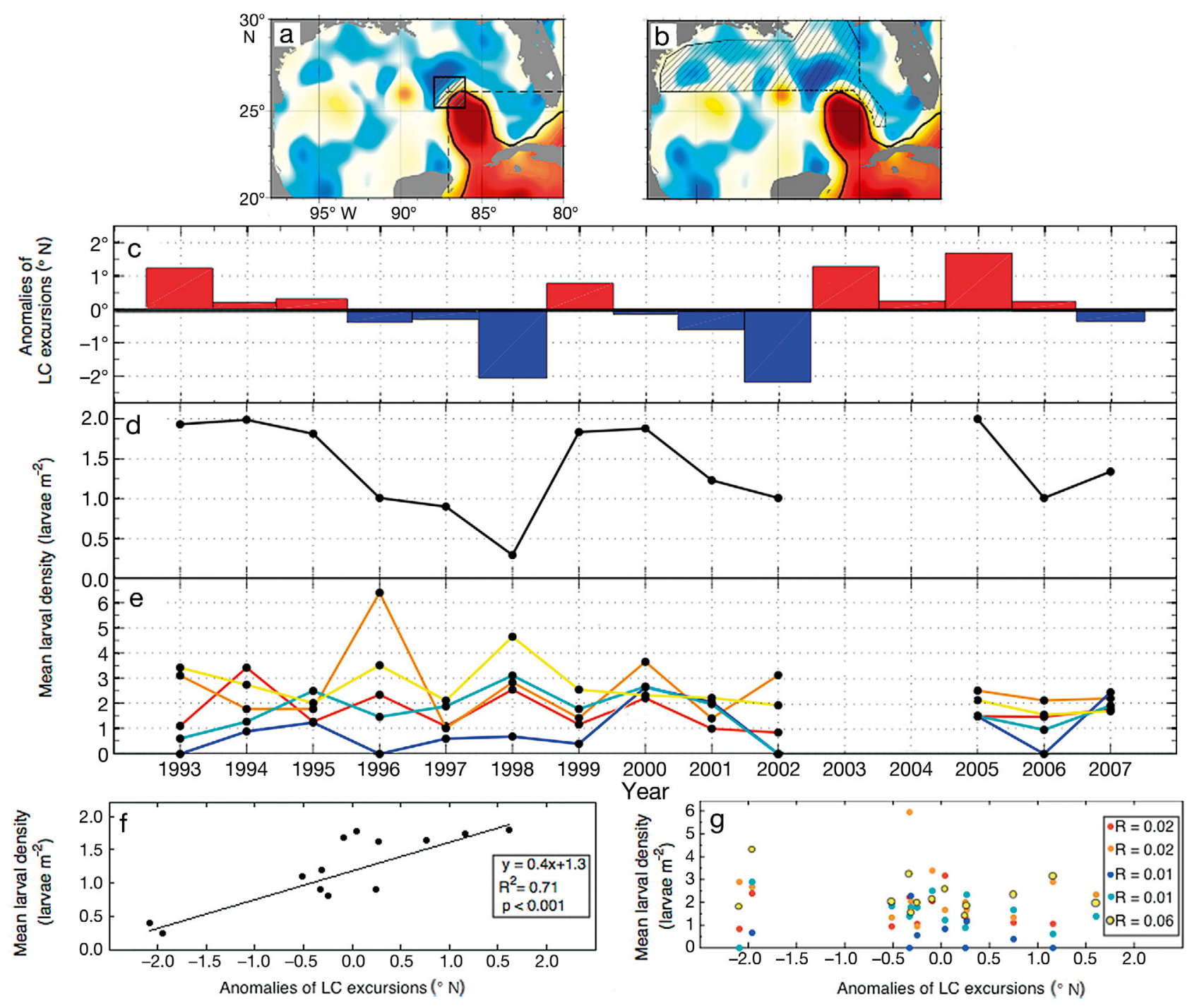

Fig. 6. (a) First location examined, a $2^{\circ}$ box centered at $87^{\circ} \mathrm{W}$ and $26^{\circ} \mathrm{N}$. (b) Second location examined, the area outside of the weekly ROI of the LC. The surface extent of this region varies weekly due to the excursions of the LC. (c) Anomalies of the mean northernmost location of the LC in spring. Spring mean larval density of (d) Thunnus thynnus, Euthynnus alleteratus, Auxis spp., Thunnus spp., and Coryphaena spp. captured in the $2^{\circ}$ box (mean larval density of all taxa from May 1993 to June 2007 , with the exception of 2003 and 2004) and (e) all taxa captured in the area out of the weekly ROI of the LC. Color code as in Fig. 3 : Red, orange, dark blue, light blue, and yellow show mean larval density of all taxa in $A R, A B, C R, C B$, and CW, respectively, from May 1993 to June 2007, with the exception of 2003 and 2004. Regression analysis of mean larval density (f) in the $2^{\circ}$ box vs. anomalies in the LC excursions and $(\mathrm{g})$ in the area out of the weekly ROI of the LC vs. anomalies in the LC excursions

from AR $(p=0.001), A B(p=0.036)$ and $C R(p=$ $0.006)$ and that $\mathrm{AB}$ was also different from $\mathrm{CR}(\mathrm{p}=$ 0.024). A species-specific test looking at presence/ absence (PA) of each taxon separately found that the PA of Thunnus thynnus was significantly different among zones $(p=0.038)$, as a result of probabilities of occurrence being higher in $\mathrm{AB}$ than $\mathrm{AR}, \mathrm{CB}$, or CR. The PA of Auxis spp. was also significantly different among zones $(\mathrm{p}=0.001)$, due to higher probabilities of occurrence in $\mathrm{CW}$ than in $\mathrm{AR}, \mathrm{CB}$, or $C R$ and higher probabilities of occurrence in $A B$ than AR. Conversely, the PA of Thunnus spp. $(\mathrm{p}=$ 0.49), Euthynnus alleteratus $(\mathrm{p}=0.45)$, and Coryphaena spp. $(\mathrm{p}=0.06)$ were not different among zones, although the PA variation of Coryphaena spp. was marginally significant.

To create a better picture of the SSH values that differentiate the mesoscale features in the GOM outside of the ROI of the LC from 1993 to 2007, each region of circulation was characterized here by its SSH minimum, maximum, mean value, and standard deviation (Table 4). 
Table 3. Proportion of positive stations (\%; P) and mean larval densities (larvae $\mathrm{m}^{-2} ; \mathrm{M}$ ) in anticyclonic regions (AR), anticyclonic boundaries (AB), cyclonic regions (CR), cyclonic boundaries (CB) and common waters (CW) for Thunnus thynnus, Euthynnus alleteratus, Auxis spp., Thunnus spp., and Coryphaena spp. Calculated from altimetry derived fields and spring sampling from 1993 to 2007

\begin{tabular}{|c|c|c|c|c|c|c|c|}
\hline Species & & AR & $\mathrm{AB}$ & $\mathrm{CR}$ & $\mathrm{CB}$ & $\mathrm{CW}$ & All features \\
\hline \multirow[t]{2}{*}{ T. thynnus } & $\mathrm{P}$ & 1.2 & 2.0 & 1.2 & 1.5 & 5.8 & 11.7 \\
\hline & M & 0.9 & 3.7 & 0.9 & 1.4 & 2.3 & 1.84 \\
\hline \multirow[t]{2}{*}{ E. alleteratus } & $\mathrm{P}$ & 0.5 & 1.4 & 0.2 & 0.3 & 5.3 & 7.7 \\
\hline & $M$ & 1.7 & 2.0 & 0.7 & 0.9 & 2.1 & 1.48 \\
\hline \multirow[t]{2}{*}{ Auxis spp. } & $\mathrm{P}$ & 1.7 & 4.5 & 0.6 & 2.0 & 14.2 & 22.9 \\
\hline & M & 2.0 & 2.7 & 2.2 & 2.3 & 3.0 & 2.44 \\
\hline \multirow[t]{2}{*}{ Thunnus spp. } & $\mathrm{P}$ & 6.2 & 7.8 & 1.5 & 3.6 & 15.9 & 35.0 \\
\hline & M & 1.8 & 2.3 & 1.8 & 1.9 & 1.9 & 1.94 \\
\hline \multirow[t]{2}{*}{ Coryphaena spp. } & $\mathrm{P}$ & 1.4 & 2.0 & 0.3 & 0.9 & 3.6 & 8.3 \\
\hline & M & 0.7 & 0.8 & 1.0 & 0.7 & 0.8 & 0.8 \\
\hline \multirow[t]{2}{*}{ All taxa } & $\mathrm{P}$ & 11.0 & 17.8 & 3.7 & 8.3 & 44.9 & 85.5 \\
\hline & M & 1.4 & 2.3 & 1.3 & 1.4 & 2.0 & 1.7 \\
\hline
\end{tabular}

\section{DISCUSSION}

The average cycle of northward penetration of the LC showed maximum values in early summer, consistent with the findings of Behringer et al. (1977). While this seasonality was not statistically significant, the oscillations of the mean latitude of the LC were positively correlated with larval fish density in the region delimited by 25 to $27^{\circ} \mathrm{N}$ and 86 to $88^{\circ} \mathrm{W}$, which was centered at the mean northernmost latitude and westernmost longitude of the LC during spring months. Thus, higher mean larval densities were found in this $2^{\circ}$ by $2^{\circ}$ region when the Loop Current intruded farther north and vice versa. This could be due to (1) physical mechanisms of northward displacement of larvae carried by the LC, but we could also hypothesize that this could be due to (2) a biological response by either adults or larvae to the LC frontal feature. The LC front

Table 4. Sea surface height (SSH) minimum (min), maximum (max), mean \pm SD of anticyclonic regions (AR), anticyclonic boundaries $(\mathrm{AB})$, cyclonic regions (CR), cyclonic boundaries (CB), and common waters (CW), calculated from the mean $\pm \mathrm{SD}$ of the $\mathrm{SSH}$ and gradient of SSH fields for each of the 5 regions, from 1993 to 2007

\begin{tabular}{|lccc|}
\hline Region & Min $(\mathrm{cm})$ & Max $(\mathrm{cm})$ & Mean \pm SD $(\mathrm{cm})$ \\
\hline $\mathrm{AR}$ & 153 & 216 & $177 \pm 15.0$ \\
$\mathrm{AB}$ & 138 & 175 & $153 \pm 5.3$ \\
$\mathrm{CR}$ & 114 & 135 & $124 \pm 4.9$ \\
$\mathrm{CB}$ & 121 & 147 & $137 \pm 5.2$ \\
$\mathrm{CW}$ & 128 & 161 & $145 \pm 5.1$ \\
\hline
\end{tabular}

may contain higher concentrations of zooplankton and other potential prey items and may therefore represent favorable habitat for adult spawning or larval growth and survival. Previous studies in the GOM region have confirmed that higher displacement volumes of plankton and densities of scombrid fish larvae may be found in LC frontal areas (Richards et al. 1989, 1993), consistent with the theory that species target spawning to locations that provide a favorable environment for their larvae (Bakun 1996). Larvae were less abundant in the core of both cyclonic and anticyclonic mesoscale features and more abundant near anticyclonic frontal areas (Table 3). This finding suggests that larval densities within the LC frontal zone may have been higher than within the main body of the current.

Larvae may be more abundant in boundaries of mesoscale features simply because these boundaries represent convergence zones where favorable prey concentrations exist (zooplankton or fish larvae). Fish larvae eat a variety of zooplankton, and some (e.g. scombrids) may eat each other (piscivory) once they are post-flexion (Kaji et al. 1996). Alternatively, adult fish may actively spawn in the vicinity of such frontal regions. There is some indication of spatial autocorrelation in the abundance of larvae from different species of fish throughout the SEAMAP time series, suggesting common spawning areas favorable for multiple fish species.

Thunnus thynnus and Auxis spp. larvae were most often present within the boundaries of anticyclonic features and in GOM common waters. However, occurrences were not different among zones for Euthynnus alleteratus $(\mathrm{p}=0.45)$, Thunnus spp. $(\mathrm{p}=$ $0.49)$, and Coryphaena spp. $(p=0.06)$. These results are similar to those from studies in the western Mediterranean (García et al. 2005, Alemany et al. 2010), in which tuna spawning grounds were related to anticyclonic features, and T. thynnus larvae were more abundant near frontal areas. Previous studies showed highest abundance of E. alleteratus and Auxis spp. eggs outside cyclonic eddies in open waters near southern Brazil (Matsuura \& Sato 1981) and in the eastern Pacific (Klawe 1963). We found Thunnus spp. larvae to be distributed more broadly and over a wider range of SSH than T. thynnus. This agrees with reports that adult tropical tunas have 
broader habitat preferences in the GOM than $T$. thynnus (Weng et al. 2009, Teo \& Block 2010), including higher tolerances for warm features (Muhling et al. 2010, Teo \& Block 2010), such as the LC and warm $\mathrm{LC}$ rings. SSH is proportional to integrated vertical water temperature (Willis et al. 2004), and our results therefore suggest higher tolerances for warm waters for these tropical tuna species. Some of the variability in larval abundances in GOM common waters may be due to smaller-scale oceanographic features, which were not apparent from an analysis that used only altimetry data. For example, small cyclonic eddies generated at irregular intervals tend to travel along the LC edge (Zavala-Hidalgo et al. 2003) and may influence larval distributions.

Larvae were typically very small, with mean lengths of $\sim 4 \mathrm{~mm}$ in bongo net samples, and were thus $\sim 7 \mathrm{~d}$ or less in age (Brothers et al. 1983, Oxenford \& Hunte 1983, Macías et al. 2006, Muhling et al. 2010). Larvae are unlikely to cross oceanographic boundaries during these early life stages, and it is therefore likely that larvae outside the LC region were collected fairly near to their spawned location in the northern GOM region. However, future work utilizing coupled physical-biological models to simulate larval movement, growth, and survivorship will provide further information on the distances that larval fish may travel after spawning and on the connectivity of populations.

The year-to-year variability of the LC has the potential to influence adult recruitment, if a stronger frontal zone leads to enhanced larval survival or retention. However, the largest fraction of the spawning habitat of Thunnus thynnus and Auxis spp., was within the boundaries of anticyclonic eddies and in GOM common waters of the northern GOM, outside of the ROI of the LC. Although further research is required on ecosystem-based responses to climate change in the region, climatic forcing can also influence larval production or survival because the potential for significant impacts on spawning of T. thynnus is high in the GOM (Muhling et al. 2011).

Recent observations in tropical and subtropical waters have demonstrated that mesoscale features, such as eddies, have a disproportionate and previously unrealized effect on plankton blooms (McGillicuddy et al. 2007). Significantly higher densities of Thunnus thynnus and Auxis spp. larvae in the boundaries of anticyclonic features, demonstrated in the present study, indicate that these smaller-scale oceanographic features may affect the life histories of some medium/large pelagic fishes. This would suggest that future research should incorporate higher resolution sampling of the biological and physical environment than generally occurs in most field studies and should attempt to resolve the extent to which the nature and frequency of formation of smaller-scale oceanographic features, such as eddies, are in fact predictably driven by larger-scale oceanographic changes (Glenn \& Ebbesmeyer 1994, Miller et al. 2005).

In conclusion, our findings based on coarse spatial resolution altimeter data show that the boundaries of anticyclonic regions contained higher densities of Thunnus thynnus and Auxis spp. larvae than the boundaries of cyclonic regions, anticyclonic regions, or cyclonic regions. This complements recent studies that define favorable habitat (Muhling et al. 2010) and annual indices (Ingram et al. 2010) of T. thynnus in the northern GOM. Finer-scale distributions of larval fish in GOM common waters may be investigated in future research by using other sources of satellite data to overlay on altimetry. Tracing frontal zones from SST and ocean color data would give more detail regarding the location of larvae relative to smaller-scale features. Studies of this type may provide further valuable information on the influence of oceanographic features on larval distribution and survival.

Acknowledgements. The altimeter products were produced by Ssalto/Duacs and distributed by AVISO, with support from the Centre National d'Études Spatiales. The authors thank J. Lyczkowski-Shultz and D. Hanisko from National Oceanic and Atmospheric Administration (NOAA) NMFS and K. Williams from the Fish and Wildlife Research Institute for providing data, helpful information and suggestions. The authors are grateful to P. Sangrà from Universidad de Las Palmas de Gran Canarias, A. Bakun from the University of Miami, and 4 anonymous reviewers for providing suggestions and comments, improving the manuscript. We also thank M. Konieczna and L. Ejsymont from the Polish Plankton Sorting and Identification Center in Szczecin, Poland. We extend our gratitude to the captains and crew of all the NOAA ships used to collect data on the SEAMAP cruises. This work is supported by the Atlantic Oceanographic and Meteorological Laboratory of NOAA. The manuscript was substantially improved by comments from anonymous reviewers and the editor, and we thank them for their time and efforts.

\section{LITERATURE CITED}

Alemany F, Quintanilla L, Vélez-Belchí P, García A and others (2010) Characterization of the spawning habitat of Atlantic bluefin tuna and related species in the Balearic Sea (western Mediterranean). Prog Oceanogr 86:21-38

Alvera-Azcárate A, Barth A, Weisberg RH (2009) The surface circulation of the Caribbean Sea and the Gulf of Mexico as inferred from satellite altimetry. J Phys Oceanogr 39:640-657 
Anderson MJ (2001) A new method for non-parametric multivariate analysis of variance. Austral Ecol 26:32-46

- Anderson MJ, Ford RB, Feary DA, Honeywill C (2004) Quantitative measures of sedimentation in an estuarine system and its relationship with intertidal soft-sediment infauna. Mar Ecol Prog Ser 272:33-48

Bakun A (1996) Patterns in the ocean: ocean processes and marine population dynamics. University of California Sea Grant, San Diego, CA, in cooperation with Centro de Investigaciones Biológicas de Noroeste, La Paz, Baja California Sur

Bakun A (2006) Fronts and eddies as key structures in habitat of marine fish larvae: opportunity, adaptive response and competitive advantage. Sci Mar 70:105-122

Behringer DW, Molinari RL, Festa JF (1977) The variability of anticyclonic current patterns in the Gulf of Mexico. J Geophys Res 82:5469-5476

Bigelow KA, Boggs CH, He X (1999) Environmental effects on swordfish and blue shark catch rates in the US North Pacific longline fishery. Fish Oceanogr 8:178-198

Blaha JP, Born GH, Guinasso NL, Herring HJ and others (2000) Gulf of Mexico ocean monitoring system. Oceanography 13:10-17

Breaker LC (1981) The applications of satellite remote sensing to west coast fisheries. Mar Technol Soc J 15:32-40

Brothers EB, Prince ED, Lee DW (1983) Age and growth of young-of-the-year bluefin tuna, Thunnus thynnus, from otolith microstructure. In: Prince ED, Pulos LM (eds) Proceedings of the international workshop on age determination of oceanic pelagic fishes: tunas, billfishes, and sharks. NOAA Nat Mar Fish Serv Tech Rep, Vol 8, p 49-59

> Candela J, Sheinbaum J, Ochoa J, Badan A, Leben R (2002) The potential vorticity flux through the Yucatan Channel and the Loop Current in the Gulf of Mexico. Geophys Res Lett 29:2059

Candela J, Tanahara S, Crepon M, Barnier B, Sheinbaum J (2003) Yucatan Channel flow: observations versus Clipper Atl6 and Mercator Pam models. J Geophys Res 108: C12 doi:10.1029/2003JC001961

- Chiswell SM, Wilkin J, Booth JD, Stanton B (2003) TransTasman Sea larval transport: Is Australia a source for New Zealand rock lobsters? Mar Ecol Prog Ser 247: 173-182

Clarke KR, Gorley RN (2006) Primer v6: user's manual/tutorial. Primer-E, Plymouth

Clarke KR, Warwick RM (2001) Change in marine communities: an approach to statistical analyses and interpretation, 2nd edn. PRIMER-E, Plymouth

> Clarke KR, Chapman MG, Somerfield PJ, Needham HR (2006) Dispersion-based weighting of species counts in assemblage analyses. Mar Ecol Prog Ser 320:11-27

> Davis CS, Wiebe PH (1985) Macrozooplankton biomass in a warm-core Gulf Stream ring: time series changes in size structure, taxonomic composition, and vertical distribution. J Geophys Res 90:8871-8884

Elliott BA (1982) Anticyclonic rings in the Gulf of Mexico. J Phys Oceanogr 12:1292-1309

Forristall GZ, Schaudt KJ, Cooper CK (1992) Evolution and kinematics of a Loop Current eddy in the Gulf of Mexico during 1985. J Geophys Res 97:2173-2184

García A, Alemany F, Vélez-Belchí P, López Jurado JL and others (2005) Characterization of the bluefin tuna spawning habitat off the Balearic Archipelago in relation to key hydrographic features and associated environmental conditions. Collect Vol Sci Pap ICCAT 58:535-549

> Glenn SM, Ebbesmeyer CC (1994) The structure and propagation of a Gulf Stream frontal eddy along the North Carolina shelf break. J Geophys Res 99:5029-5046

> Ingram GW Jr, Richards WJ, Lamkin JT, Muhling B (2010) Annual indices of Atlantic bluefin tuna (Thunnus thynnus) larvae in the Gulf of Mexico developed using deltalognormal and multivariate models. Aquat Living Resour 23:35-47

Kaji T, Tanaka M, Takahashi Y, Oka M, Ishibashi N (1996) Preliminary observations on development of Pacific bluefin tuna Thunnus thynnus (Scombridae) larvae reared in the laboratory, with special reference to the digestive system. Mar Freshw Res 47:261-269

Klawe WL (1963) Observations on the spawning of four species of tuna (Neothunnus macropterus, Katsuwonus pelamis, Auxis thazard, and Euthynnus lineatus) in the eastern Pacific Ocean, based on the distribution of their larvae and juveniles. Inter-Am Trop Tuna Comm Spec Rep 6:447-540

Le Traon PY, Nadal F, Ducet N (1998) An improved mapping method of multisatellite altimeter data. J Atmos Ocean Technol 15:522-534

Lee TN, Leaman K, Williams E, Berger T, Atkinson L (1995) Florida Current meanders and gyre formation in the southern Straits of Florida. J Geophys Res 100: 8607-8620

Liu Y, Weisberg RH, Hu C, Kovach C, Riethmüller R (2011) Evolution of the Loop Current system during the Deepwater Horizon oil spill event as observed with drifters and satellites. In: Liu Y et al. (eds) Monitoring and modeling the Deepwater Horizon oil spill: a record-breaking enterprise, Geophys Monogr Ser, Vol 195. Am Geophys Union, Washington, DC, p 91-101

Macías D, Lema L, Gómez-Vives MJ, Ortiz de Urbina JM, de La Serna JM (2006) Some biological aspects of small tunas (Euthynnus alletteratus, Sarda sarda \& Auxis rochei) from the southwestern Spanish Mediterranean traps. Collect Vol Sci Pap ICCAT 59:579-589

Matsuura Y, Sato G (1981) Distribution and abundance of scombrid larvae in southern Brazilian waters. Bull Mar Sci 31:824-832

> Maul GA, Vukovich FM (1993) The relationship between variations in the Gulf of Mexico Loop Current and Straits of Florida volume transport. J Phys Oceanogr 23:785-796

Maul GA, Williams F, Roffer M, Sousa FM (1984) Remotely sensed oceanography patterns and variability of bluefin tuna catch in the Gulf of Mexico. Oceanol Acta 7: 469-479

McGillicuddy DJ Jr, Anderson LA, Bates NR, Bibby T, and others (2007) Eddy/wind interactions stimulate extraordinary mid-ocean plankton blooms. Science 316: 1021-1026

Medina A, Abascal FJ, Megina C, García A (2002) Stereological assessment of the reproductive status of female Atlantic northern bluefin tuna during migration to Mediterranean spawning grounds through the Strait of Gibraltar. J Fish Biol 60:203-217

Miller AJ, Di Lorenzo E, Neilson DJ, Kim H and others (2005) Interdecadal changes in mesoscale eddy variance in the Gulf of Alaska circulation: possible implications for the Stellar sea lion decline. Atmos-Ocean 43:231-240

> Molinari RL (1980) Current variability and its relation to seasurface topography in the Caribbean Sea and the Gulf of Mexico. Mar Geod 3:409-436 
Molinari RL, Mayer JD (1982) Current meter observations on the continental slope at two sites in the eastern Gulf of Mexico. J Phys Oceanogr 12:1480-1492

Muhling BA, Lamkin JT, Roffer MA (2010) Predicting the occurrence of Atlantic bluefin tuna (Thunnus thynnus) larvae in the northern Gulf of Mexico: building a classification model from archival data. Fish Oceanogr 19: 526-539

Muhling BA, Lee SK, Lamkin JT, Liu Y (2011) Predicting the effects of climate change on bluefin tuna (Thunnus thynnus) spawning habitat in the Gulf of Mexico. ICES J Mar Sci 68:1051-1062

Muller-Karger FE, Walsh JJ, Evans RH, Meyers MB (1991) On the seasonal phytoplankton concentration and sea surface temperature cycles of the Gulf of Mexico as determined by satellites. J Geophys Res 96:12645-12665

Nakata H, Kimura S, Okazaki Y, Kasai A (2000) Implications of meso-scale eddies caused by frontal disturbances of the Kuroshio Current for anchovy recruitment. ICES J Mar Sci 57:143-152

Oey LY, Lee HC, Schmitz WJ Jr (2003) Effects of winds and Caribbean Eddies on the frequency of Loop Current eddy shedding: a numerical model study. J Geophys Res 108:3324

Oey LY, Ezer T, Lee HC (2005) Loop Current, rings and related circulation in the Gulf of Mexico: a review of numerical models and future challenges. In: Sturges W, Lugo-Fernández A (eds) Circulation in the Gulf of Mexico: observations and models, Vol 161. Am Geophys Union, Washington DC, p 31-56

> Okazaki Y, Nakata H, Kimura S (2002) Effects of frontal eddies on the distribution and food availability of anchovy larvae in the Kuroshio Extension. Mar Freshw Res 53:403-410

Ortner PB, Wiebe PH, Haury L, Boyd S (1978) Variability in zooplankton biomass distribution in the northern Sargasso Sea: the contribution of Gulf Stream cold core rings. Fish Bull 76:323-334

Ortner PB, Ferguson RL, Piotrowicz SR, Chesal L, Berberian G, Palumbo AV (1984) Biological consequences of hydrographic and atmospheric advection within the Gulf Loop Intrusion. Deep-Sea Res Part A 31:1101-1120

Oxenford HA, Hunte W (1983) Age and growth of dolphin, Coryphaena hippurus, as determined by growth rings in otoliths. Fish Bull 84:906-909

Polovina JJ, Kleiber P, Kobayashi DR (1999) Application of TOPEX-POSEIDON satellite altimetry to simulate transport dynamics of larvae of spiny lobster, Panulirus marginatus, in the northwestern Hawaiian Islands, 1993-1996. Fish Bull 97:132-143

Powell BS, Leben RR, Ginasso NL (2006) Comparison of buoy and altimeter-derived shelf currents using an optimal operator. IEEE Geosci Remote Sens Lett 3:192-196

Rabalais NN, Carney RS, Escobar-Briones EG (1999) Overview of continental shelf benthic communities of the Gulf of Mexico. In: Kumpf H, Steidinger K, Sherman K (eds) The Gulf of Mexico large marine ecosystem: assessment, sustainability, and management. Blackwell Science, Malden, MA, p 171-195

Editorial responsibility: Alejandro Gallego, Aberdeen, UK
Richards WJ, Leming T, McGowan MF, Lamkin JT KelleyFraga S (1989) Distribution of fish larvae in relation to hydrographic features of the Loop Current boundary in the Gulf of Mexico. ICES Mar Sci Symp 191:169-176

Richards WJ, Leming T, McGowan MF, Lamkin JT, Kelley S (1993) Larval fish assemblages at the Loop Current boundary in the Gulf of Mexico. Bull Mar Sci 53:475-537

> Richardson DE, Llopiz JK, Leaman KD, Vertes PS, MullerKarger FE, Cowen RK (2009) Sailfish (Istiophorus platypterus) spawning and larval environment in a Florida Current frontal eddy. Prog Oceanogr 82:252-264

$>$ Rio MH, Hernandez F (2004) A mean dynamic topography computed over the world ocean from altimetry, in situ measurements, and a geoid model. J Geophys Res 109: C12032

Royer F, Fromentin JM, Gaspar P (2004) Association between bluefin tuna schools and oceanic features in the western Mediterranean. Mar Ecol Prog Ser 269:249-263

Rudorff CAG, Lorenzzetti JA, Gherardi DFM, Lins-Oliveira JE (2009) Modeling spiny lobster larval dispersion in the Tropical Atlantic. Fish Res 96:206-215

Ryan EH, Mariano AJ, Olson DB, Evans RH (1996) Global sea surface temperature and currents. Eos Trans AGU 77:46

> Shay LK, Mariano AJ, Jacob SD, Ryan EH (1998) Mean and near-inertial ocean current response to hurricane Gilbert. J Phys Oceanogr 28:858-889

Shipp RL (1999) Status of exploited fish species in the Gulf of Mexico. In: Kumpf H, Steidinger K, Sherman K (eds) The Gulf of Mexico large marine ecosystem: assessment, sustainability, and management. Blackwell Science, Malden, MA, p 196-204

> Sturges W, Evans JC (1983) On the variability of the Loop Current in the Gulf of Mexico. J Mar Res 41:639-653

- Sturges W, Leben R (2000) Frequency of ring separations from the Loop Current in the Gulf of Mexico: a revised estimate. J Phys Oceanogr 30:1814-1819

Teo SLH, Block BA (2010) Comparative influence of ocean conditions on yellowfin and Atlantic bluefin tuna catch from longlines in the Gulf of Mexico. PLoS ONE 5:e10756

> Weng KC, Stokesbury MJW, Boustany AM, Seitz AC, Teo SLH, Miller SK, Block BA (2009) Habitat and behaviour of yellowfin tuna Thunnus albacares in the Gulf of Mexico determined using pop-up satellite archival tags. J Fish Biol 74:1434-1449

> Willis JK, Roemmich D, Cornuelle B (2004) Interannual variability in upper-ocean heat content, temperature, and thermosteric expansion on global scales. J Geophys Res 109:C12036 doi: 10.1029/2003JC002260

Wilson SG, Lutcavage ME, Brill RW, Genovese MP, Cooper AB, Everly AW (2005) Movements of bluefin tuna (Thunnus thynnus) in the northwestern Atlantic Ocean recorded by pop-up satellite archival tags. Mar Biol 146: 409-423

Zavala-Hidalgo J, Morey SL, O'Brien JJ (2003) Cyclonic eddies northeast of the Campeche Bank from altimetry data. J Phys Oceanogr 33:623-629

Zavala-Hidalgo J, Morey SL, O'Brien JJ, Zamudio L (2006) On the Loop Current eddy shedding variability. Atmósfera 19:41-48

Submitted: April 18, 2011; Accepted: June 4, 2012

Proofs received from author(s): August 21, 2012 